\title{
Industry and EUROTECH: Partners in International Engineering Education
}

\author{
Richard P. Long and Kandace Einbeck \\ University of Connecticut
}

\section{INTRODUCTION}

As the U.S. seeks to expand its foreign trade, the need for American engineers capable of functioning in the global marketplace increases. These engineers must be capable of understanding cultures other than their own and must develop some skills with foreign languages. Developing an international engineering program in an English speaking country requires considerable analysis. There are many cultures and languages from which to choose. How can an engineering school intending to make these opportunities available to its students, identify the best way to proceed? An analysis of local industry indicated that German was the best choice for the State of Connecticut.

The need for engineers educated to function in the global marketplace is well known in industrial circles, but to make engineering students aware of the career advantages of this path is difficult. One of the problems is the demanding nature of the engineering undergraduate program. The limited career vision of young students beginning the freshman year of engineering requires that the opportunities be packaged in an enticing program and properly presented. To overcome these impediments and attract the students to a program of study that will enhance their careers, we incorporated several items into the five-year, dual degree EUROTECH Program: an internship abroad, study toward an additional degree in German, lectures in technical subjects in German, and the use of German-speaking engineers as role models. Described herein is the cooperation between industry and the School of Engineering at the University of Connecticut that resulted from this choice.

\section{INDUSTRIAL INTERESTS}

Connecticut is a small state with a substantial base of sophisticated manufacturing. Jet engines, helicopters, elevators, and tools are but a few of the products produced in the state by companies founded in the U.S. but now having a presence in foreign countries of which Germany seems to be a frequent location. Of the foreign subsidiaries in the State, German firms are the most numerous by a wide margin, having more than 80 . In addition the State Legislature signed a Sister-State agreement with the State of Baden-Württemberg in Germany in 1991 and since then about 238 students from Connecticut universities have participated in the various opportunities that the agreement provides. In the past several years, officials from the State of Connecticut have visited Germany twice with the desire of attracting more companies to locate subsidiaries in the state. 


\section{DEVELOPING EUROTECH}

German emerged as the best target for culture and language study in an international engineering program, and we had to make sure that industry would support such an initiative. From members of the Connecticut Legislature we learned of several enthusiastic administrative officers in industry and discussed the project with them. Letters of support from both the legislature and industry accompanied the proposal that was prepared and submitted to the U.S. Department's Fund for the Improvement of Post-Secondary Education. EUROTECH received funding of $\$ 250,000$ to develop the program.

Although Germany is the initial target country for EUROTECH few high schools in Connecticut offer this language, so the program had to begin with elementary German. The most valuable aspect of an international program is working and living abroad. It is very difficult if not impossible to incorporate sufficient language training into a four year engineering program to allow either work or study abroad. The inclusion of the six-month internship abroad increases the length of study to more than four years. It is reasonable therefore to complete an additional year and earn a additional degree from an area in the Liberal Arts. In addition to the credits needed in the major there are also additional General Education Requirements for a degree in German so the education of the engineering student is broadened through EUROTECH.

The engineering student working in a foreign land requires a vocabulary that includes technical terms, that the typical language student does not need. The faculty in foreign languages does not normally include this capability, so to prepare EUROTECH students for their internships abroad and to keep up their interest in the program German-speaking engineers and scientists must participate. There is usually some capability among the engineering and science faculty of each university in various foreign languages, and Connecticut is blessed with an industrial base that includes many native German-speaking engineers and scientists. Use of these engineers not only provides the student with a technical vocabulary but also with German-speaking role models. Lectures by these engineers is only possible through their cooperation and that of the companies for which they work.

\section{FORMING THE ADVISORY BOARD}

The fledgling program had many needs, both immediate and long term. The immediate need was to tap into the pool of German-speaking engineers in local industry. Two courses were built around their availability as guest lecturers. The long-term-needs included funds for Scholarships and other program costs. Help was requested from the development officer in the School of Engineering, who had the contacts and experience dealing with industry. The industrial officers visited were busy people with many demands on their time. Although they felt the concept of EUROTECH was a good one, most were reluctant to become involved. After visits to several companies, we found the president of one who was interested in helping us get things started. He in turn called others and convinced them to participate, and the External Advisory Board was begun. 
Identifying the board members during EUROTECH's first fall semester, allowed the first board meeting to take place the following January. The opening remarks by the deans of both the School of Engineering and the College of Liberal Arts and Science showed the enthusiasm of the University and set the positive tone that continues today. To help with the work of establishing EUROTECH, the board was divided into three subcommittees: education, internships, and institutionalization. The full board meets twice a year in the fall and spring. For the first several years of operation, the subcommittees met one or more times between board meetings to work on assigned tasks.

\section{ACTIVITIES OF THE ADVISORY BOARD}

\section{Contributions to Education}

The education subcommittee addresses EUROTECH's needs in the classroom setting. The subcommittee suggested that industry contribute by providing guest speakers for courses, printed materials and tools for demonstration purposes, and opportunities for field trips to their industrial firms each semester. These contributions would allow students to become familiar with activities of practicing engineers.

One of the most productive opportunities for interaction between industry and the academy in the EUROTECH Program has been the role that guest speakers play in our courses in technical German. What better way for a beginning or intermediate level student to hear language on a technical subject in action than from someone who is both a practicing engineer and a native German-speaker? Each semester we invite three or four German-speaking engineers working at international firms in Connecticut to give short presentations (approximately thirty minutes) to our fourth and fifth semester classes: Introduction to Sciences and Fields of Technology, one-credit courses taken in addition to the students' regular courses in German. These guest speakers present German lectures on topics fundamental to the various engineering disciplines, the natural sciences and mathematics. The German teacher provides preparation for the lectures in the week before the lecture and conducts discussion sessions the week following the presentation. The students are required to prepare questions on the material and pose these questions to the speaker in German. Some of the speakers presenting in the past two semesters are listed with their topics in the appendix. Our advisory board members have been very helpful in this regard, by giving some presentations themselves or steering us to potential speakers within their companies and of course releasing their time.

Using guest speakers from industry offers several advantages. First and foremost, these speakers provide expertise in their fields of engineering. This supplements the knowledge of the German language instructor who, thanks to them, does not have to become an instant specialist in chemical engineering, helicopter technology or electron-beam welding! It is a true partnership. The guest speaker provides the technical expertise - in the German language of industry. The language teacher helps the students understand, manipulate and apply the language learned. Our

guest speakers supply the topic, and often an outline, graphics for overheads, vocabulary lists of technical vocabulary used in the presentation or occasionally, the entire text of the presentation. 
It is up to us to then didacticize this material, which we do by:

a. collecting and analyzing vocabulary - sifting out the words that will be important for the students in other contexts in the future from those what are relevant only for this lecture and therefore need not be acquired by the students.

b. analyzing style - teaching those structures of technical German that may not have been encountered or emphasized in the students' regular language classes.

c. providing activities and opportunities for students to use the material in writing and speaking.

Second, the students in the class come from all engineering disciplines at the University, Chemical Engineering, Civil and Environmental Engineering, Computer Science and Engineering, Electrical Engineering, and Mechanical Engineering. Inviting guest speakers from various industries provides a variety of topics, corresponding to the varied interests of the students. Having the course in the hands of one professor of engineering would not allow for this variety.

Thirdly, the guest speakers provide "role models" for our students in both language and engineering. They are native German-speakers with a variety of accents, provide authentic input, and as practicing engineers, in industry, they give our students a glimpse into the world that they are about to enter as beginning engineers ${ }^{1}$. The students see that engineers do work in international settings and that engineering truly is a profession that crosses borders. Moreover, their use of technical language reinforces and authenticates the discourse in the technical register which the students have encountered in the technical German classes.

There are, of course, certain disadvantages. The teacher must indeed relinquish some measure of control over the course syllabus, as each speaker chooses his or her own topics. Teaching such a course involves contacting the speakers prior to the semester, making sure necessary video equipment is available and functioning, reconfirming dates, and maintaining a contingency plan in case the guest speaker's busy schedule suddenly forces the cancellation of a talk. One needs to provide speakers with information about who the audience is and what their level of language ability is, how long the talk should be (beginning language learners are unable to maintain the level of concentration necessary to listen to much more than 20-30 minutes of sustained speech in the target language), and should be encouraged to bring visuals which can provide the extra-linguistic information needed to make their presentations understood by beginners.

Sometimes the guest speaker is unable to provide much material beforehand. Then the language teacher must scramble to find materials to use in the preparation phase and hope that they will at least be tangentially related to what they (students and teachers) will all hear for the first time in the lecture. Since guest speakers and topics change quite a bit each semester, the course must be reconstructed for each term. As there are no text books available for beginning German for engineers, this material must be constructed, and new exercises and activities written for each speaker's presentation, sometimes on a moment's notice. It is very important to prepare the students for each presentation. The student will be dealing with unfamiliar language and may 
be dealing with unfamiliar engineering, especially with a speaker who is not in that particular discipline. At least one of these unknowns must be explained beforehand or the students find themselves in the impossible position of trying to solve for two variables with one equation and wind up frustrated in the process ${ }^{2}$.

Sometimes the very thing that is an advantage on the one hand, i.e. authentic input, becomes a disadvantage. The authentic language of the presentation may be more than, the optimal level of language difficulty in a language learning situation ${ }^{3}$. This may be due to the fact that the speakers may have had little or no previous experience lecturing in their native language to beginning, non-expert listeners, or because his or her accent may be unusual, or because the speaker may just naturally have a rapid way of speaking. The very things mentioned above, positive when encountered in moderation, may become a disadvantage when too far removed from the norm that the students are used to in their previous instruction.

Nevertheless, the rewards gained from incorporation of guest speakers far outweigh the potential problems. Few of the fears mentioned above have been realized. The guest speakers have been clear, have used plenty of visuals, and have brought interesting contributions. Sometimes a guest lecture has extended an invitation for us to visit the speaker's company on a field trip, where the students have been able to observe first hand the processes, machines and techniques that they had already encountered in the classroom lecture. We try to plan a field trip at least once per semester. These visits to firms, open to all students in the program, have reinforced the classroom instruction of those students in the aforementioned courses and whetted the appetite of the students who will be in the course in upcoming semesters.

\section{Assistance with Internships}

Internships are an integral part of EUROTECH. The search for German internships was begun with companies represented on the board then expanded through various sources. One very helpful source was the Fraunhofer Society who set up a series of appointments in Germany. A total of 30 companies were visited in Germany during a three year period. At each visit our program and goals were described and discussed. A firm commitment for internships was not requested, only consideration of our students as interns when they apply. This approach was readily accepted, because the companies can make their decisions based on current economic conditions. In a year of tight operating budget and conditions a company may not be able to take on any of our students as interns.

An important piece of information that was obtained from these meetings and subsequent talks with German universities concerned the nature of the internship periods for German engineering students. There are actually two periods of industrial experience for students. The first, called the Grundpraktikum, occurs in many cases before the student begins studying at the university. The second called the Ingenieurepraktikum comes later after three or four years of study. Since we indicated that we would like our students to have a internship on the level of the Ingenieurpraktikum the companies indicated that they would like our students to have some industrial experience in the U.S. before they come to Germany. Members of the board have been 
very helpful in providing assistance for these summer internships.

In Germany the Praktikum is considered an extension of the learning the student gets at the university. The knowledge that the student is expected to get from the job site is prescribed, often to the number of weeks of each type of experience. American universities have no similar requirement. Cooperative work is probably the closest American activity but the type of experience is usually not specified. For the first few EUROTECH student the work experience was not specified, and the companies supplying the Praktikum were somewhat at a loss as to what to do with our students. The situation was corrected by the students negotiating for the type of work experience that satisfied them, but this method of operating was anything but ideal. A questionnaire was drafted to obtain information on what type of work experiences a company may have available, the conditions of work including compensation, and the name of the supervisor to whom the student would be assigned.

The draft questionnaire was taken to the advisory board for review and advice. German members of the advisory board saw the problem immediately, and recommended that we name the internship in Germany a Praxissemester. They also made several important suggestions for specific items on the questionnaire.

\section{Institutionalization}

The fact that we have encountered an overwhelmingly positive response from industry has sent a signal to the University's administration that EUROTECH is a program that is necessary and desirable for today's engineers and therefore worthy of financial support by the university. They have demonstrated their support of the program by their contributions of time and effort as members of the advisory board and as speakers and by their contributions of funds for scholarships, publicity and internships .

In return, the university has designated a tenure-track position in German dedicated to the EUROTECH program. By attending board meetings, the Dean and the Director of Development of the School of Engineering have seen the enthusiasm of the board and their contributions. Their presence working with the board makes this a true partnership at the institutional level.

\section{CONCLUSION}

What have we learned from this partnership? We have learned that the partnership has not only been essential in the development of the program in its fledgling stages, as expected, but that the importance and the diverse roles that our partners from industry have played have actually increased and expanded over the years. A program such as EUROTECH could not survive as an entity unto itself. The walls of the ivory tower have been breached and must remain so, if we are to offer international engineering education relevant in a global society.

\section{ACKNOWLEDGMENT}


As stated above initiation of this project was supported by the U.S. Department's Fund for the Improvement of Post-Secondary Education. A similar program had already been established at the University of Rhode Island using German as the target language and culture. J. Grandin director of URI's program has made several recommendations and suggestions. His assistance is greatly appreciated. Martin Hirschorn, Development Officer of the School of Engineering, helped make the External Advisory Board become a reality. Regina Kecht served as Co-Director of EUROTECH for three years before leaving the University.

\section{REFERENCES}

1. Omaggio,A. 1986. Teaching Language in Context: Proficiency Oriented Instruction. Boston: Heinle \& Heinle, p. 47

2. Grandin, J.M., K. Einbeck, and W. Reinhart. 1992. "The Changing Goals of language Instruction" in Languages for a Multicultural World in Transition, Heidi Byrnes, Ed. Lincolnwood, IL NTC, pp 150-151

3. Krashen, S. D. and T. Terrell. 1983. The Natural Approach: Language Acquisition in the Classroom. Hayward, CA: the Alemany Press, pp. 32-33.

Biographical Notes

Prof. RICHARD P. LONG, (Ph.D. Rensselaer Polytechnic Institute) is a Geotechnical Engineer, who has been a member of the Civil and Environmental Engineering Faculty at the University of Connecticut for thirty years. He has served as a director of EUROTECH for the School of Engineering from its inception in 1993, and has attended the Goethe Institute in Frankfurt, Germany.

KANDANCE EINBECK, (Ph.D. University of Connecticut) has been Visiting Assistant Professor of German at the University of Connecticut since January 1997. For five years, she was associate director of a similar program, the International Engineering Program at the University of Rhode. She has spent several years teaching in Germany and Austria. 


\section{APPENDIX}

\section{EUROTECH Guest Speaker Presentations 1997}

INTRODUCTION TO THE SCIENCES

Spring Semester 1997

\begin{tabular}{|c|c|c|c|}
\hline Guest Speaker & $\begin{array}{c}\text { Company } \\
\text { Represented }\end{array}$ & Presentation Title & $\begin{array}{c}\text { Follow-up Plant } \\
\text { Tours }\end{array}$ \\
\hline Günther Schubert & $\begin{array}{c}\text { PTR Precision } \\
\text { Technologies Enfield } \\
\text { CT }\end{array}$ & $\begin{array}{c}\text { Electron-beam } \\
\text { Welding }\end{array}$ & $\begin{array}{c}\text { PTR Enfield, CT } \\
\text { April 1997 }\end{array}$ \\
\hline Wilfried Meier & $\begin{array}{c}\text { Sikorsky Aircraft } \\
\text { Stratford CT }\end{array}$ & Helicopters & Index Corporation \\
Shelton, CT & $\begin{array}{c}\text { Development of } \\
\text { Computer Controlled } \\
\text { Turning Machines }\end{array}$ & $\begin{array}{c}\text { Index in Esslingen, } \\
\text { Germany, May'97 }\end{array}$ \\
\hline Günther Schubert & $\begin{array}{c}\text { Trumpf, Inc. } \\
\text { Farmington, CT }\end{array}$ & $\begin{array}{c}\text { Positioning of } \\
\text { Machine Tools with } \\
\text { Laserinterferometers }\end{array}$ & $\begin{array}{c}\text { Trumpf in Ditzinger, } \\
\text { Germany, May '97 } \\
\text { Farmington, CT } \\
\text { Oct. '97 }\end{array}$ \\
\hline
\end{tabular}

\section{FIELDS OF TECHNOLOGY}

Fall Semester 1997

\begin{tabular}{|c|c|c|}
\hline Axel Werner & $\begin{array}{l}\text { United Technologies } \\
\text { Research Center, } \\
\text { East Hartford, CT }\end{array}$ & $\begin{array}{l}\text { Machining as a } \\
\text { Process }\end{array}$ \\
\hline Ulrike Klüh & $\begin{array}{l}\text { Dept. of Chemical } \\
\text { Engr. Univ. of Conn. }\end{array}$ & $\begin{array}{l}\text { Determination of } \\
\text { K1A in Fermenters }\end{array}$ \\
\hline Günter Zinken & $\begin{array}{l}\text { Torrington Co. } \\
\text { (Ingersoll-Rand), } \\
\text { Torrington, CT }\end{array}$ & $\begin{array}{l}\text { Sample Cages for } \\
\text { Small Needle } \\
\text { Bearings }\end{array}$ \\
\hline
\end{tabular}


Session 3561

\begin{tabular}{|c|c|c|c|}
\hline Roland Warmuth & $\begin{array}{c}\text { MAN Roland } \\
\text { Groton, CT }\end{array}$ & $\begin{array}{c}\text { Modern Print } \\
\text { Processes }\end{array}$ & $\begin{array}{c}\text { Field Trip planned } \\
\text { for Spring '98 }\end{array}$ \\
\hline
\end{tabular}

